УДК 655.3.022.14: 655.05

\title{
ЕКСПЛУАТАЦІЙНІ ВЛАСТИВОСТІ ВІДБИТКІВ СТРУМИННОГО ДРУКУ
}

\author{
( В. Б. Нетак, УАД, Львів, Україна
}

\begin{abstract}
Изложены результаты исследований эксплуатационных свойств оттисков струйной печати. Проведен анализ факторов влияющих на оттиски, определены особенности изменения оттисков под воздействием этих факторов.
\end{abstract}

The results of researches of operating properties of inprints of stream printing are expounded. The analysis of factors, which influence on inprints is conducted. Features of change of inprints under act of these factors are also conducted.

\section{Постановка проблеми}

Враховуючи зростання попиту і власне сфери застосування відбитків струминного друку (оформлення інтер'єрної реклами в офісах, короткотривалі вивіски і оголошення), його невисоку собівартість і відсутність дорогого програмного забезпечення у більшої кількості користувачів, котре полегшує вибір матеріалів і параметрів друку, постає потреба у представлені ім рекомендацій стосовно найбільш поширених матеріалів для їх вибору, при друкуванні відбитків, котрі будуть вимагати певних експлуатаційних параметрів для якісного зберігання інформації, котру вони несуть протягом певного часу. Звісно виявлення залежності між певними параметрами матеріалів і експлуатаційними характеристиками відбитків допомогло б значно краще оцінювати потенційні можливості у застосуванні відбитків при наявності матеріалів із певними відомими характеристиками.
Звісно постає потреба у визначені експлуатаційних характеристик. Немає значення чи говорити про якесь оголошення, котре буде висіти на стовпі чи дошці протягом декількох днів, чи про відбиток видрукуваний на банерній тканині для того щоб провисіти на вулиці протягом місяця, головними критеріями до них буде стійкість до впливу сонячного світла і води, тобто вологи, тобто зберегти свої кольори, а отже і інформацію, незмінними протягом максимально можливого часу.

В даній роботі було досліджено відбитки, отримані в стандартних умовах струминного друку, проведено оцінку їхньої якості і співставлень з властивостями паперів.

\section{Мета роботи}

Дослідити експлуатаційні властивості відбитків. Визначити особливості зміни якості відбитків під впливом чинників умов навколишнього середовища. 


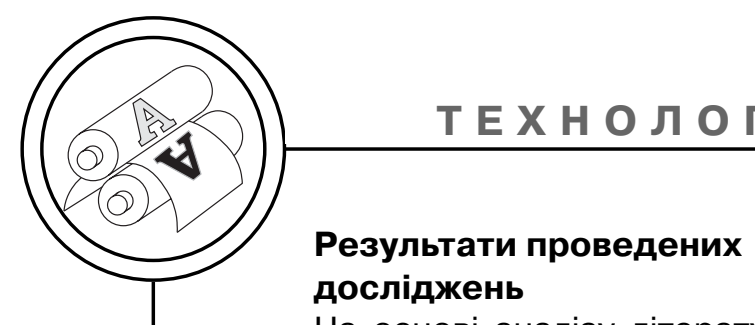

На основі аналізу літературних відомостей, а також популярності, поширеності і доступності різноманітних матеріалів для дослідження обрані наступні матеріали:

1. Polcopy $80\left\ulcorner/ \mathrm{M}^{2} \mathrm{IP}\right.$ Kwidzyn.

2. Pollux $80\left\ulcorner/ \mathrm{M}^{2} \mathrm{IP}\right.$ Kwidzyn.

3. Polspeed $80 r / \mathrm{M}^{2}$ IP Kwidzyn.

4. Poljet $80 г / \mathrm{M}^{2}$ IP Kwidzyn.

5. Computer Print - Out Papier $70 \Gamma / \mathrm{M}^{2}$ IP Kwidzyn.

6. Laser Printing Paper $80 г / \mathrm{M}^{2}$ IP Kwidzyn.

7. Neusiedler satynowany 120 $\Gamma / \mathrm{M}^{2}$.

8. Agfa nablyszczany i satynowany $195 \mathrm{r} / \mathrm{M}^{2}$.

9. Epson Photo Paper Quality Ink Jet Paper $194 \mathrm{r} / \mathrm{M}^{2}$.

10. TDK Premium nablyszczany $215 \mathrm{r} / \mathrm{M}^{2}$.

Фактично дані папери (група 1-7) можна легко зустріти у більшості офісів, маленьких видавництвах і в приватному вжитку, група 8-10 являе собою також досить популярні види так званих фотографічних паперів.

Задруковування паперів відбувалося на принтері фірми Hewlett Packard DeskJet 930C тестовим зображенням на якому знаходилися наступні елементи, виконано у програмі Corel Draw 9:

- кольорові площини із змінним насиченням від 0 до 100 \% в основних кольорах СMYK;

- кола з концентрично збігаючимися лініями CMYK, а також кольорові кола у 4 основних кольорах;
- зразки шрифтів Arial i Times New Roman;

- літери різної величини на чорному фоні;

- різнокольорова графіка для візуальної оцінки.

Видрукувані примірники піддали денситометричним вимірюванням на денситометрі Gretag D 182, а також спектроденситометрі X-Rite.

Стійкість відбитків до дії світла визначали вимірюванням оптичної густини зображення у 12-ти характерних місцях відразу після друкування і через сім днів.

Дослідження стійкості відбитків до дії води полягало у нанесенні на відбитки крапель дистильованої води та в наступній візуальній оцінці.

З метою вдосконалення денситометричних методів дослідження впроваджено критерій, що полягає на зоровій оцінці якості друку. Для візуальної оцінки відбитків використано наступні елементи:

- Кольорова картинка.

- Кола $з$ кольорами, що концентрично збігаються.

- Зразки шрифтів Arial i Times New Roman.

Отже критеріями оцінки якості відбитків були:

- Стійкість відбитків до дії світла, що визначали вимірюванням оптичної густини зображення у 12-ти характерних місцях відразу після друкування i через сім днів.

- Стійкість відбитків до дії води, дослідження котрої полягало у нанесенні на відбитки крапель дистильованої води та в наступній візуальній оцінці. 
- Візуальна оцінка якості відтворення елементів і кольорів.

Візуальна оцінка видруків, отриманих для паперів 1-7, була порівнянна для усіх проб. Виконані відбитки характеризувалися відносно добрим відтворення кольорів, а також зразків шрифту. Не спостерігалося явище розпливання чорнила, навіть при друкуванні найменшої подробиці, якою була літера, величиною 4 пункти. Переміщення фарби в центр кіл зауважувалося для усіх проб лише при використанні збільшувального скла. Трохи вище, порівняно з рештою паперів, відтворення фарб спостерігалося у випадку папеpy 7 .

Фотографічні папери відзначалися кращим, порівняно з паперами 1-7, відтворенням фарб. В обговорюваній групі найкращим був папір 10. На добру візуальну оцінку цієї проби мав вплив, ймовірно, той факт, що блиск окремих фарб був нижчий від блиску незадрукованого паперу. Найслабшим був папір 8, що пов'язано між іншим 3 найнижчою в цій групі паперів білизною. При використанні лупи можна було зауважити розпливання найменшого елементу шрифта, а також мінімальне проникнення чорнила поза контур шрифту Arial.

Результати денситометричних вимірювань показали, що найменші різниці перед і після виставлення видруків під дію світла виступали у випадку жовтої фарби, натомість найбільші різниці відзначено відносно блакитної фарби. У групі паперів $1-7$ найбільше відпірним на дію світла була проба 6, а найменше проба 3.

У групі фотографічних паперів найбільше відпірний на дію сонячних променів був папір 9. Різниці перед і після насвітлення були мінімальні. Відносно найвищі різниці у вимірах отримано для зразка 10.

Таблиця 1

Основні фізичні властивості досліджуваних паперів

\begin{tabular}{|c|c|c|c|c|c|c|c|c|c|c|}
\hline $\begin{array}{l}\text { Номер } \\
\text { проби }\end{array}$ & 1 & 2 & 3 & 4 & 5 & 6 & 7 & 8 & 9 & 10 \\
\hline $\begin{array}{l}\text { Воло- } \\
\text { гість, \% }\end{array}$ & 4,8 & 4,0 & 4,3 & 4,4 & 5,2 & 3,9 & 4,1 & 4,4 & 5,4 & 3,9 \\
\hline $\begin{array}{l}\text { Товщина, } \\
\text { мм }\end{array}$ & 0,102 & 0,099 & 0,094 & 0,100 & 0,088 & 0,130 & 0,121 & 0,187 & 0,220 & 0,219 \\
\hline $\begin{array}{l}\text { Гладкість, } \\
\text { с, } \\
\text { сторона А }\end{array}$ & 99,73 & $\begin{array}{c}108 \\
40\end{array}$ & $\begin{array}{c}105 \\
40\end{array}$ & 93,00 & $\begin{array}{c}101 \\
10\end{array}$ & 69,50 & $\begin{array}{c}237 \\
00\end{array}$ & $\begin{array}{c}4096 \\
50\end{array}$ & 72,80 & $\begin{array}{c}2811, \\
50\end{array}$ \\
\hline Сторона В & 86,50 & $\begin{array}{c}106 \\
30\end{array}$ & 89,80 & 89,70 & 80,90 & 74,74 & $\begin{array}{c}215 \\
40\end{array}$ & - & - & - \\
\hline $\begin{array}{l}\text { Погли- } \\
\text { нальність, } \\
\text { мм }^{-1}\end{array}$ & $\begin{array}{l}29 \\
660\end{array}$ & $\begin{array}{l}29 \\
110\end{array}$ & $\begin{array}{l}28 \\
620\end{array}$ & $\begin{array}{l}26 \\
770\end{array}$ & $\begin{array}{l}29 \\
710\end{array}$ & $\begin{array}{l}31 \\
820\end{array}$ & $\begin{array}{l}24 \\
890\end{array}$ & 7,070 & $\begin{array}{l}27 \\
160\end{array}$ & 7,080 \\
\hline $\begin{array}{l}\text { Ступінь } \\
\text { проклей- } \\
\text { ки, г/м² }\end{array}$ & $\begin{array}{l}16 \\
200\end{array}$ & $\begin{array}{l}28 \\
200\end{array}$ & $\begin{array}{l}25 \\
300\end{array}$ & $\begin{array}{l}26 \\
400\end{array}$ & $\begin{array}{l}20 \\
200\end{array}$ & $\begin{array}{l}24 \\
700\end{array}$ & $\begin{array}{l}25 \\
500\end{array}$ & $\begin{array}{l}14, \\
200\end{array}$ & $\begin{array}{l}43 \\
800\end{array}$ & $\begin{array}{l}44 \\
600\end{array}$ \\
\hline
\end{tabular}




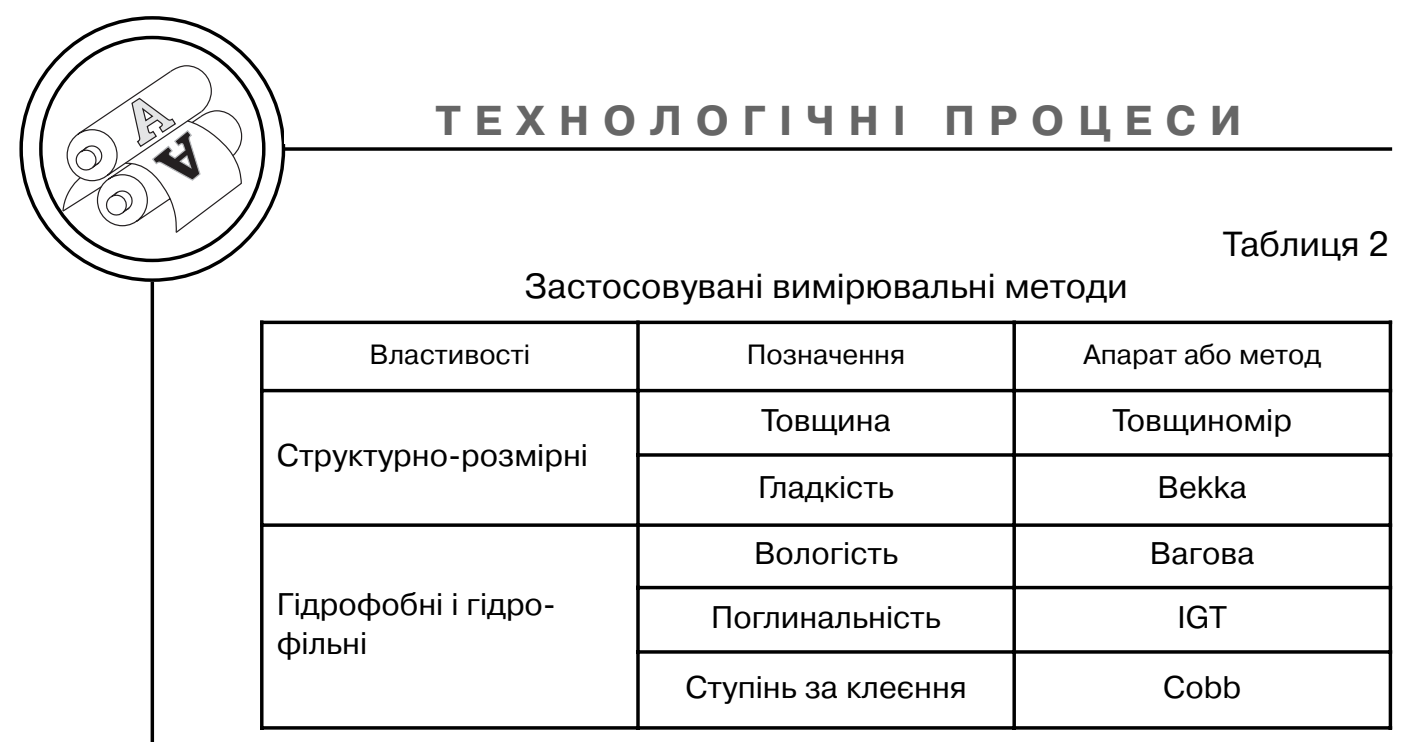

3 метою визначення залежності якості отриманих відбитків (їх фарбо-передачі, стійкості до впливу умов навколишнього середовища) від властивостей паперів, було проведено дослідження структурно-розмірних, гідрофобних і гідрофільних характеристик матеріалів. Результати досліджень представлено у таблиці 1.

Основні властивості паперів визначено за наступними вимірювальними методами (табл. 2).

Методика дослідження властивостей відбитків наведена в [7].

3 отриманих результатів можна зробити висновки, що досліджувані експлуатаційні характеристики відбитків не залежать від структурно-розмірних і гідрофільних властивостей матеріалів. Можна припустити, що вплив на експлуатаційні характеристики мають оптичні характеристики матеріалів, а також їх склад.

\section{Висновки}

Загалом візуальна оцінка якості видруків, виконаних на поверхнях досліджуваних па- перів, показує, що відображення усіх навіть найменших елементів було відносно хорошим. Добрі структурно-розмірні параметри, відносно низька ціна паперів 1-7, а також можливість отримання справді якісних відбитків забезпечує цим паперам першу позицію серед матеріалів, які використовувалися для офісних і домашніх цілей. Натомість використання фотографічних паперів для виконання відбитків гарантує фотографічну якість картинки, високу інтенсивність фарб, однак незаперечно підвищує вартість відбитків.

Старіння видруків не зумовило істотних змін в ї кольористиці. Якщо говорити про відпірність видруків на дію вологи, спостерігалося лише невелике розмивання фарби під впливом нанесеної краплі води. Проте необхідно звернути увагу, що відпірність видруків на вологість залежить не лише від роду паперу, але й від виду чорнила, а отже і від принтера. У зв'язку з цим той самий папір може показувати різні властивості водовідпірності при відбитках отриманих на різних принтерах. 
1. Бачинський Л., Демянишин Д., Микитів Н. Якість відбитків широкоформатних принтерів // Большой формат. - 2004. - № 3. - С. 24-27. 2. Величко О. М., Зоренко О. В., Кириченко І. О. Практикум із загального та поліграфічного матеріалознавства. - К.: НТУУ «КПI». - 2006. - 150 с. 3. Войтенко С., Демянишин Д., Микитів Н. Ринок і перспективи застосування нових технологій? // Большой формат. - 2005. - № 3- С. 30-31. 4. Демянишин Д. В., Нетак В. Б., Гуменюк В. О. Якість відбитків широкоформатного друку та їх експлуатаційні характеристики // Технологія і техніка друкарства. - 2007. - № 3-4. - С. 41-48. 5. Гнатишак О., Демянишин Д., Нетак В., Румянцев Ю. Для чого використовується широкоформатний цифровий друк? // Большой формат. - 2005. - № 2. - С. 22-24. 6. Лабораторний практикум з поліграфічного матеріалознавства. За загальною редакцією д.Х.н., проф. В. В. Шибанова. - Л.: Афіша. - 2001. - 180 с. 7. Демянишин Д. В., Нетак В. Б., Гуменюк В. О. Якість відбитків широкоформатного друку та їх експлуатаційні характеристики // Технологія і техніка друкарства. - 2007. - № 3-4. - С. 41-48.

Рецензент - О. М. Величко, д.т.н., с.н.с., професор, НТУУ «КП।» 